\title{
The German private company limited partnership
}

\author{
by Frank Wooldridge
}

\section{INTRODUCTORY REMARKS}

$\mathrm{T}$ he German private company limited partnership ( $\mathrm{GmbH} \& \mathrm{Co} \mathrm{KG}$ ) is the commonest form of partnership in use in Germany. As is evident from its name, it is a hybrid type of legal entity, consisting of a limited partnership between a private company and other persons, who are called Kommanditisten and have limited liability. As is explained in detail below, several forms of such partnerships exist in Germany, as do certain other corresponding forms of hybrid legal entity. These consist for example of the $\mathrm{GmbH} \& \mathrm{Co} \mathrm{KGaA}$, which is a limited partnership with shares, in which the unlimited partner is a private company, The permissibility of using this type of legal entity was confirmed by the Federal Supreme Court in 1997: see Juristenzeitung (JZ) 11, 1997, p 2. There is also the Stiftung \& Co KG, a limited partnership in which the unlimited partner (Komplementar) is a foundation, - such entities began to be formed in the 1980's - and the Auslanderkapitalgesellschaft \& Co KG, a limited partnership in which the limited partner is an overseas capital company. Limited partnerships are of considerably more importance in Germany than in the UK or France.

Although certain German text-writers have expressed their objection to the $\mathrm{GmbH}$ \&Co $\mathrm{KG}$ (which has sometimes been used for improper purposes) the legality of this hybrid form of legal entity was affirmed by the Court of Appeal of Bavaria in 1912 (see GmbH Rundschau 1914, 9) and by the Supreme Court of the Reich in 1922 (RGZ 105, 101); the latter decision was affirmed by the Federal Supreme Court in 1955 (see GmbH Rundschau, 1957, 38). The widespread use of the $\mathrm{GmbH} \& \mathrm{Co} \mathrm{KG}$ in Germany has often been attributed to certain tax advantages it enjoyed until 1976. These were that its income was not subject to the taxation both at the level of the legal entity and that of the holder of the relevant interest, as was income from capital companies.

The use of the GmbH \& Co KG has continued to grow very considerably in Germany since 1976. The reasons for this include the fact that it is more difficult to remove the managers of such an entity than in the case of a $\mathrm{GmbH}$. Where a private company is a member of the limited partnership, this ensures that it will survive the death of one of its members. The impact of the rules governing codetermination is reduced in the case of the $\mathrm{GmbH} \& \mathrm{Co}$ KG; see paras 1,4 and 5 of the Codetermination Act 1976, as amended. Until a Community Directive of 1990 was implemented in Germany by the Companies and Partnerships Directive Act 2000, which added a new paragraph 264a to the Commercial Code, the private company limited partnership was not required to have its accounts audited and published unless it was of a very large size. (See Council Directive 90/605/EC, OJL317/6 of 6 November 1996, p 60; implementation of this Directive in Germany was delayed for many years, and see now BGBI 2000, 1,152 for the relevant implementing Act).

Although the establishment of a $\mathrm{GmbH} \& \mathrm{Co}$ KG requires careful drafting, such an entity often proves to be of a flexible character. It is not only used by family businesses, but also by other types of business, some of which have hundreds of partners and are listed on a stock exchange (Publikums GmbH \& Co KG or Publikumsgesellschaft). The unlimited liability of the $\mathrm{GmbH}$ in a GmbH \& Co KG may be of little benefit to creditors where such a $\mathrm{GmbH}$ has inadequate assets to meet their claims. The minimum capital of such an entity is only $€ 25,000$.

German text-writers treat a $\mathrm{GmbH} \& \mathrm{Co} \mathrm{KG}$ as a property held in joint ownership rather than as a legal person. A limited partner in such an entity is, according to paragraph 171(1) of the Commercial Code, directly liable to the creditors of the company up to the amount of his contribution. This liability is excluded once the contribution has been paid. Such a limited partner in a $\mathrm{GmbH} \& \mathrm{Co} \mathrm{KG}$ which pursues a commercial activity before it is registered, may also incur unlimited liability in accordance with paragraph 176 of the Commercial Code, which is dealt with below.

\section{THE RESPONSIBLE ENTITY: LIABILITY FOR EXECUTIONS}

The purpose and function of the private company is to act as the legal person which is treated as carrying on the relevant activities in the limited partnership ( $\mathrm{GmbH} \& \mathrm{Co}$ $\mathrm{KG})$. A $\mathrm{GmbH} \& \mathrm{Co} \mathrm{KG}$ must carry on a commercial activity which is of a substantial kind, or be entered in the Commercial Register (paras 1 and 2, Commercial Code). The requirement that a commercial activity should be carried on has sometimes given rise to difficulties. It should be emphasised that the legal entity responsible for the undertaking is not the private company, but the $\mathrm{GmbH}$ \& Co KG. However, the GmbH is the representative body of the limited partnership, and is represented by its manager (Geschäftsführer), who acts in the name of the 
partnership. A German limited partnership is said to be governed by the principle of Selbstorganschaft according to which its management and representation is entrusted to the unlimited partner.

The distinction between the $\mathrm{GmbH}$ and the limited partnership is of importance for the purpose of determining liability for executions on the basis of a court judgment. If the judgment is against the limited partnership execution may be levied against its assets: where the judgment is against the company, execution may be levied against the latter's assets.

\section{NAMES}

Both the $\mathrm{GmbH}$ and the limited partnership must have names; the name of the partnership will normally be used in transactions with third parties. This name must be taken from that of the unlimited partner (para 19(2), Commercial Code), but may also include the name of one of the limited partners. Furthermore, it is clear from paragraph 24 of the German Commercial Code that the name may be taken from that of the former owner of a business, or a former unlimited partner in a limited partnership, which has been converted into a $\mathrm{GmbH} \& \mathrm{Co}$ KG. Paragraph 24(1) provides that if a person is admitted as a partner to an existing business, or if a new partner withdraws from such a business, then the present business name can be continued, despite the change, even though it contains the name of the former owner of the business, or the names of partners. According to paragraph 30(1) of the Commercial Code, the name must be such as to distinguish the undertaking from other undertakings in the same district. The name must be followed by an indication making clear the nature of the undertaking (para 19(5), Commercial Code), for example GmbH \& Co KG. It is not clear what the consequences are of omitting such an indication.

\section{TYPES OF GMBH \& CO KG}

In a typical $\mathrm{GmbH} \& \mathrm{Co} \mathrm{KG}$ there is just one unlimited partner (Komplementär) consisting of a private company $(\mathrm{GmbH})$. The purpose and function of the $\mathrm{GmbH}$ is simply to act as such an unlimited partner. However, a GmbH \& Co KG does not necessarily have these two characteristics. It may thus have more than one unlimited partner. Where, as is usually the case, it has only one such partner, the relevant private company may itself be responsible for running another business, or may act as an unlimited partner in more than one limited partnership.

As already indicated, a GmbH \& Co KG may have a considerable number of members and seek investments from the public. At one time $\mathrm{GmbH} \& \mathrm{Co} \mathrm{KG}$ enjoyed special tax advantages in relation to the writing off of losses and were especially popular in the construction industry. Such advantages appear to have diminished, and the popularity of such large entities has also suffered from the fact that they have acquired a somewhat unfortunate reputation, because they have often resulted in financial failures. The present article will be principally concerned with the smaller and personalistic type of $\mathrm{GmbH} \& \mathrm{Co} \mathrm{KG}$; the $\mathrm{GmbH} \& \mathrm{Co} \mathrm{KG}$ which takes the form of a Publikumsgesellschaft is governed by the rules considered below, but encounters special problems relating to its structure, the maintenance of its capital and the protection of its creditors.

One must differentiate between those $\mathrm{GmbH} \& \mathrm{Co} \mathrm{KG}$ in which the private company and the limited partnership are comprised of the same persons, and those where no such identity of personnel is present. Such an identity of personnel is commonly but not inevitably found in the family type of undertaking, but will be absent in the $\mathrm{GmbH}$ \& Co KG which is a Publikumsgesellschaft. When a GmbH \& Co KG of personalistic type is formed, care must be taken to provide for the harmonisation of the legal provisions governing the limited partnership and the GmbH.

A single person $\mathrm{GmbH}$ \& $\mathrm{Co} \mathrm{KG}$ is recognised under German law. In such an entity, the same person is sole shareholder of the private and sole member of the limited partnership. A sole trader may form such an entity in order to limit his liability. However, the single member $\mathrm{GmbH} \&$ Co KG will remain responsible for the debts incurred by the sole trader in the course of the business. The single member will himself incur liability for such debts for a period of five years after the formation of the limited partnership. As K Schmidt points out (op cit p 1637) the statutes of the $\mathrm{GmbH}$ should contain a provision releasing the sole shareholder from the prohibition of contracting with his company contained in paragraph 35(4) GmbHG. The limited partner and the shareholder in the private company do not have to be natural persons, and may well be a holding company (note in this sense, K Schmidt, Gesellchattsrecht 3rd ed, pub Carl Heymanns Verlag 1997, p 1636).

The above type of entity must be distinguished from a unitary (Einheits) GmbH \&Co KG. In such an entity, the limited partnership is sole shareholder in the GmbH. The limited partners usually abandon their role as members of the $\mathrm{GmbH}$, and transfer their shares to the $\mathrm{GmbH} \& \mathrm{Co}$ KG. The business of the latter entity is conducted by the $\mathrm{GmbH}$, which represented by its manager. Thus, it is ensured that the functioning of the $\mathrm{GmbH}$ and of the limited partnership are coordinated. However, difficulties arise in relation to the dismissal of the manager or his release from liability (Entlastung). The latter is prevented from voting on such issues (which according to para 46(5) GmbHG, must be dealt with the company's general meeting) by paragraph 47(4) GmbHG.

The remedy which is used to escape this situation is to give the limited partners the right to vote at meetings of the GmbH. It has been contended that the need to resort to this device demonstrates the doubtful legality of the $\mathrm{GmbH}$ 
\& Co KG, which has in the event to be regarded as a somewhat artificial construction. Onemay come to the same conclusion as to artificiality in relation to the single person $\mathrm{GmbH} \& \mathrm{Co} \mathrm{KG}$, considered above. Both entities owe their existence (as does the $\mathrm{GmbH} \& \mathrm{Co} \mathrm{KG}$ ) to the ingenuity of jurists rather than to the legislature.

The two tier or several tier GmbH \& Co KG is a further type of the relevant entity. This consists of a combination of at least three undertakings. Thus a private company may be the unlimited partner in a limited partnership $(\mathrm{GmbH}$ \& Co $\mathrm{KG}$ ) which in turn is the unlimited partner in a further limited partnership ( $\mathrm{GmbH} \& \mathrm{Co} \mathrm{KG}$ ). However, it appears that if the intermediate entity does not pursue any business activity, and simply acts as an unlimited partner in another entity difficulties may arise: the intermediate limited partnership will not be recognised as a $\mathrm{GmbH}$ \& Co KG but will be entitled to be regarded as a civil partnership (Gesellschaft bürgerlichen Rechts), which will give rise to certain problems, (note in this sense K Schmidt, Der Betrieb 1994, p 95 et seq) even though it is recognised that such a partnership may be a member of a limited partnership.

\section{THE FORMATION OF A GMBH \& CO KG}

Such an entity may be formed by means of the creation of two new entities, a limited partnership and a $\mathrm{GmbH}$ (which will be the unlimited partner); or by the creation of a limited partnership to which an existing $\mathrm{GmbH}$ is transferred. As already indicated, it is necessary to coordinate the rules governing both entities.

When a $\mathrm{GmbH}$ is formed for the purpose of acting as an unlimited partner in a $\mathrm{GmbH} \& \mathrm{Co} \mathrm{KG}$, it will have to conform to the normal rules governing such companies. Thus, for example, the company's statutes must be in a notarial form (para 2, GmbHG), and the minimum capital must be $€ 25,000$ (para 5(1) GmbHG, and see also paragraph 7(2) GmbHG). The object of the company must be set out in its statutes: they must make it clear that it consists of acting as the personally liable member of a limited partnership (para 3(1), sentence $2 \mathrm{GmbHG}$ ).

Paragraph 11(1) GmbHG provides that a private company does not exist before it is entered in the Commercial Register: such entry is required by paragraph $10 \mathrm{GmbHG}$. However, this rule has not been treated as binding in practice. German textwriters have generally accepted that a private company which has not been entered in the Commercial Register has some kind of existence; some have contended that a private company in the process of formation, must be regarded as a civil partnership, whilst others have argued that it should be treated as an association lacking legal capacity. The German Supreme Court (note in particular BGHZ 51, 50 and BGHZ 80, 179) has stated that a private company in the process of formation in a sui generis entity which is governed by the rules contained in the GmbH Gesetz and its statutes, to the extent that such rules do not depend for their application on the registration of the company.

It is generally accepted that a private company in the process of formation may be the unlimited partner in a GmbH \& Co KG. The Supreme Court so decided in an important judgment at March 9, 1981 - BGHZ 80; 129; see also BGHZ 117, 823. This judgment was given at a time when the Supreme Court had abandoned the principle (see BGHZ 65, 378) which prohibited the $\mathrm{GmbH}$ from contracting obligations prior to its formation (Vorbelastungsverbot). However, in its 1981 decision, the Supreme Court adopted the view that the managers of the private company could only enter into transactions on behalf of the limited partnership if they had the consent of the founders of the company.

Nevertheless, it is contended by Professor Karsten Schmidt that such transactions may be entered into between the managers and third parties on behalf of the limited partnership without any need for such consent (op cit, p 1641). His view is based upon the provisions of paragraphs 125 et seq and 161(2) of the Commercial Code. If the limited partnership is bound, this implies that the $\mathrm{GmbH}$ in the process of formation is liable for the relevant transactions as an unlimited partner. Furthermore, paragraph 11(2) GmbHG imposes personal liability for pre-registration transactions on the persons who entered into them on behalf of the $\mathrm{GmbH}$, and thus on its managers. There are considerable doctrinal disputes as to whether such unlimited liability towards creditors also applies to the founders of the $\mathrm{GmbH}$ in the process of formation. After the private company has been registered, the founders are responsible for the difference between the value of assets at the date of registration and the nominal capital.

The registration of a $\mathrm{GmbH} \& \mathrm{Co} \mathrm{KG}$ is not prevented by the fact that one of its members is a private limited company undergoing formation. It has been held by the Supreme Court that the use of the future name of any $\mathrm{GmbH} \& \mathrm{Co} \mathrm{KG}$, including one which does not pursue a commercial activity is enough to exclude unlimited liability. This follows from a decision of the Supreme Court in 1985: however, an indication may be placed in the Commercial Register (BGH NJW 1985, 737) stating that the private company is in the process of formation (in Gründung). This indication will be removed once the $\mathrm{GmbH}$ is formed.

The position of an unregistered GmbH \& Co KG differs according to whether or not it pursues an activity which is commercial by nature. If it does not pursue such an activity, it is treated as a civil partnership between the future limited partners and the $\mathrm{GmbH}$ undergoing formation. Prospective limited partners in such a GmbH \& Co KG do not incur liability under paragraph $176(1)$ of the Commercial Code, because this text requires the carrying on of a profession which is commercial by nature. 
Paragraph 176(1) provides that under certain conditions, the limited partners in such a limited partnership incur unlimited liability for transactions entered into before registration. This liability is only imposed on limited partners who consent to the beginning of business, and is excluded where a creditor knows he is dealing with a limited partner. Although the present type of $\mathrm{GmbH} \& \mathrm{Co}$ KG is treated as a civil partnership, the Federal Supreme Court has taken the view that it is possible to limit the liability of the members of such a partnership, provided that such a limitation is made apparent in the undertaking's statutes, and is evident to third parties.

It has been held that by the Supreme Court that the use of the future name of the GmbH \& Co KG is sufficient to exclude unlimited liability. Where an unregistered $\mathrm{GmbH}$ \& Co KG pursues an activity which is commercial by nature, it is treated as being a commercial partnership and not a civil one. However, until such registration, its limited partners will incur unlimited liability for transactions entered into by the entity, provided they have agreed to the commencement of business. Nevertheless, paragraph 176(2) of the Commercial Code provides that such liability is excluded where the creditor was aware that the member was only a limited partner. Such unlimited liability is excluded where the future name of the $\mathrm{GmbH} \& \mathrm{Co} \mathrm{KG}$ has been used when contracting. Where the managers of the $\mathrm{GmbH}$ have used such a name when contracting, the limited partners are also excluded from liability.

\section{LEGAL POSITION OF THE PARTNERS}

As already indicated, the managers of the $\mathrm{GmbH}$ carry on the business of the partnership. The limited partners must make cash contributions or contributions in kind to the partnership, in accordance with the partnership agreement. The latter agreement may contain a clause requiring the limited partners to accept unlimited responsibility, or to be responsible for the partnership's obligations instead of the GmbH. It is often found in practice that a $\mathrm{GmbH}$ is not required to participate in the profits and losses of the partnership. It has been suggested that the inclusion of such a clause in the agreement results in an extension of the liability of the limited partners, and an exclusion of that of the unlimited partners (such a clause is often accompanied by a further one, exempting the $\mathrm{GmbH}$ from making a capital contribution to the partnership). Such a conclusion has serious implications for the limited partners, and may be unfounded. However, it may be desirable to exclude this possibility by a specific clause in the agreement.

The partnership agreement should contain provisions regarding the transfer of shares in the partnership and in the private company. The transfer of shares in a private company is governed by paragraph 15 of the GmbHG, which permits the imposition of restrictions on the transfer of shares. It will prove desirable to harmonise the provisions in the partnership agreement and in the private company's statutes concerning the transfer of shares.

Shareholders in a $\mathrm{GmbH}$ have an extensive right to information concerning the circumstances of the company, and the right to inspect its books and records in accordance with paragraph 51a GmbHG. Such information and inspection may be refused on certain grounds. Because a $\mathrm{GmbH}$ has unlimited liability for transactions entered into by the limited partnership, its members have extensive rights to information concerning the latter entity. However, a person who is only a limited partner, and is not also a shareholder in the GmbH, has a less extensive right to information, under paragraph 166 of the Commercial Code, which is available against the limited partnership only. Shareholders in the $\mathrm{GmbH}$ who are also limited partners have rights of information. The restricted right to information included in paragraph 166(1) of the Commercial Code consists of the right to request written communication of annual accounts, and to check their correctness having examined the books and documents. By paragraph 166(3) of the Commercial Code, when important grounds exist, the court may order the communication of a balance sheet and profit and loss account or certain clarifications as well as the making available of books and papers.

\section{MEETINGS}

In a $\mathrm{GmbH} \& \mathrm{Co} \mathrm{KG}$, decisions are made by two separate bodies, the meeting of all the partners, and that of the GmbH. A general meeting of a $\mathrm{GmbH}$ may be replaced by a written consultation of the members (para 48(2) $\mathrm{GmbHG})$. The functions of the general meeting are principally set out in paragraph $46 \mathrm{GmbHG}$, but a private company is not bound by this provision, and may extend or subtract from this model. Decisions are generally taken by majority voting: every $€ 50$ of a share carries one vote (para 47(1) and (2) $\mathrm{GmbH})$. Certain decisions have to be taken by an enhanced majority.

The limited partners do not participate in the meetings of members of the GmbH. However, it has been contended that because many decisions taken by $\mathrm{GmbH}$ have an important impact upon the limited partners where the $\mathrm{GmbH}$ is the unlimited partner in a GmbH \& Co KG the members of such a GmbH must take account of the interests of the limited partnership as well as those of their own company. This may well be true where the limited partnership is of a personalistic nature. (A very helpful account of meetings in a $\mathrm{GmbH} \& \mathrm{Co} \mathrm{KG}$ occurs in a comparative work by A Guineret-Brobbel Dorsman, La $\mathrm{GmbH} \&$ Co KG Allemand et la Commendite à Responsabilité Limitée francaise, pub L.G.D.J. 1999, pp 332-38).

German law requires that certain decisions should be taken by all the partners in a limited partnership, but does not contain any special rules concerning meetings of such partners. Thus, for example the partners are required by 
paragraph 131(2) of the Commercial Code to decide on the dissolution of the partnership. Although nothing appears in the Commercial Code about this matter, it is generally thought that the partners have to approve the annual balance sheet. Although there appears to be some doubts about this matter, it would seem that the partners have to take decisions about extraordinary matters (see RGZ 158, 302). It should be noted that, because the $\mathrm{GmbH} \& \mathrm{Co} \mathrm{KG}$ is a partnership, the relevant partnership agreement may extend or reduce the number of decisions which have to be taken by the future partners. Where the unlimited partner and the limited ones consist of the same persons, it is usually thought necessary to coordinate the workings of the two different entities by means of including special provisions in the partnership agreement governing such matters as the required majorities for passing resolutions, the calling of meetings and the taking of decisions (see K Schmidt, op cit, p 1649).

It appears possible to exclude a limited partner from voting at a partners' meeting: such exclusion will not have effect where it is proposed to impose additional obligations on, or withdraw rights from such a partner. If the unlimited partner $(\mathrm{GmbH})$ has no shares in the partnership, it is often excluded from voting at partnership meetings. The general view appears to be that such exclusion is permissible, but there are some textwriters who take a different view of this matter (see Wiedemann, Gesellschaftsrecht, vol 1, pub Munich 1980, p 368).

\section{MANAGEMENT}

As is made clear by several paragraphs of the Commercial Code, (see paras 161(2), 114, 125, 164 and 170) the management and representation of a $\mathrm{GmbH} \& \mathrm{Co}$ $\mathrm{KG}$ is entrusted to the unlimited partner, ie the $\mathrm{GmbH}$. The task of managing the latter body and representing it in transactions with third parties is given to the managers (Geschäfsfuihrern - paras 35 and $37 \mathrm{GmbH}$ ). The manager of a $\mathrm{GmbH}$ is in breach of his duty towards the company if he fails to exercise the degree of care and skill required of a conscientious businessman when carrying out his duties. The private company is liable for the breaches of duty of its managers in accordance with paragraph 31 of the German Civil Code.

The question has been much discussed in Germany as to whether the managers of the $\mathrm{GmbH}$ are directly liable to the $\mathrm{GmbH} \& \mathrm{Co} \mathrm{KG}$. It appears that in a limited number of cases they may be liable to the GmbH \& Co KG in tort, in accordance with the general rules contained in paragraphs 823 et seq of the German Civil Code. However, they may incur contractual liability towards the limited partnership. Such liability is not grounded on the basis of an implied contract with the GmbH \& Co KG, but on a different one. The view has been taken by the German Supreme Court that a contract having a protective effect for a third party exists for the benefit of the limited partnership (note, for example, BGHZ 49, 350 and BGHZ
61, 227). It appears that most German jurists now accept the approach taken by the Supreme Court.

\section{EMPLOYEE PARTICIPATION}

A $\mathrm{GmbH}$ or other undertaking which employs more than 500 workers has to establish a works council in accordance with paragraph 2 of the Works Councils Act 2001. For the purpose of establishing a works council, a $\mathrm{GmbH}$ and $\mathrm{ambH} \& \mathrm{Co} \mathrm{KG}$ are regarded as independent bodies, and if each of them employ more than 500 persons, they will each have to have a works council. The latter is composed of representatives of employees, and participates in many decisions concerning them. (paras 35 and $37 \mathrm{GmbH}$ ). Many of its tasks are set out in paragraph 80 of the Works Councils Act 2001.

German public and private companies are required to have employee representation on the supervisory board (Aufsichtsrat) if certain requirements are fulfilled. A public or private company employing more than 500 persons, and no more than 2,000 persons must, according to paragraph 1 of Part 1 of the Act Simplifying Codetermination on the Supervisory Board of 18 May, 2004, have a supervisory board one third of whose members are representatives of the employees. The recent Act does not apply to the $\mathrm{GmbH} \& \mathrm{Co} \mathrm{KG}$ as opposed to the GmbH. It is frequently the case that the $\mathrm{GmbH}$ in such a limited partnership does not employ more than 500 persons.

A different approach was adopted however, in the Codetermination Act 1976. According to paragraph 4(1) of this Act (which introduced a quasi-paritative system of codetermination), a $\mathrm{GmbH}$ which is a partner in a $\mathrm{GmbH}$ \& Co KG must establish an Aufsichtsrat on which the employees and shareholders are equally represented if certain conditions are fulfilled. These are that the majority of limited partners, calculated on the basis of the majority of shares or votes possess the majority of the shares or votes in the $\mathrm{GmbH}$; that the $\mathrm{GmbH}$ does not have a business undertaking of its own employing more than 500 employees; and that the limited partnership as a whole employs more than 2,000 persons. The employees of the limited partnership may participate as electors or candidates when the supervisory board of the relevant $\mathrm{GmbH}$ is elected. Because the $\mathrm{GmbH}$ is responsible for managing the limited partnership, its supervisory board may consider such management. This possibility is obviously increased by the fact that the employees of the limited partnership may participate as electors or candidates when the supervisory board is elected.

When the requirements of paragraph 4(1) of the Codetermination Act 1976 are fulfilled, it follows from paragraph 4(2) of that Act that the GmbH cannot be excluded from the management of the undertaking. The latter provision is intended to prevent a reduction in the powers of the supervisory board. Paragraph 5(2) of the Codetermination Act 1976 contains somewhat complex 
provisions governing the situation where the private company which is a member of a $\mathrm{GmbH} \& \mathrm{Co} \mathrm{KG}$ is the dominant company in a group of companies. The employees of the companies in such a group are, for the purpose of applying the Act deemed to the employees of the private company.

The provisions of paragraphs 4 and 5 are only likely to be of practical importance for large GmbH \& Co KG, some of which may be Publikumsgesellschaften. However, smaller GmbH\&Co, which may include Publikumsgesellschaften, may set up consultative, controlling, or supervisory bodies of various kinds, either at the level of the limited partnership or at that of the GmbH. Even if the latter is not subject to one of the codetermination laws requiring employee participation, it may set up a supervisory board, to which certain of the rules contained in the Aktiengesetz (law governing public companies) are applicable. The tasks given to such bodies vary, and employees do not necessarily have any role to play in them (a good account of such bodies appears in A Guineret-Brobell Dorsman, op cit pp 358-60).

\section{REQUIREMENTS CONCERNING CAPITAL}

Both the $\mathrm{GmbH}$ and every limited partner must provide the company with capital. If a limited partner fails to do so, it follows from paragraph 171 of the Commercial Code that he is liable to creditors for the unpaid amount of his contribution. The need to make two different contributions cannot be circumvented by means of the use of the Einheits - GmbH \& Co KG. Thus, paragraph 172(6) sentence 1 of the Commercial Code provides that insofar as the creditors of an undertaking which has no natural person as a personally liable member are concerned, the contributions of the limited partners are treated as not being made, insofar as they consist of shares in the personally liable members. It is necessary to ensure that the contributions of the limited partners are received by the limited partnership and those to the limited company are received by that company. Problems have arisen in practice because it has not been properly understood that relevant payments should be made into separate bank accounts and retained therein.

As far as the GmbH \& Co KG is concerned, there are no legal provisions comparable to paragraphs 30 and 31 GmbH. Paragraph 30(1) provides that assets necessary for the purpose of maintaining the company's share capital must not be returned to it. Paragraph 31(1) provides that payments which are made in contravention of paragraph 30 must be returned to the company. Although the making of payments out of the assets of the limited partnership is not forbidden, paragraph 172(4) sentence 1 of the Commercial Code provides that insofar as the contribution of a limited partner is repaid it is treated as having not been made as far as the creditors are concerned.
In the case of a $\mathrm{GmbH} \& \mathrm{Co} \mathrm{KG}$ is concerned, such payments may have an indirect effect upon the $\mathrm{GmbH}$ which is the unlimited partner, and result in the application of paragraphs 30 and $31 \mathrm{GmbHG}$. Thus, in a case heard by the Supreme Court in 1973 (BGHZ 60, 324) the sole limited partner in a $\mathrm{GmbH} \& \mathrm{Co} \mathrm{KG}$ in bankruptcy was also a member of the $\mathrm{GmbH}$ which had a capital of 20,000DM. The KG had paid the debts amounting to $115,000 \mathrm{DM}$ owed by the limited partner to the tax authorities in respect of a period prior to the formation of the limited partnership. Its judicial administrator requested the repayment of these debts. The Supreme Court held that the payments made were in contravention of paragraph 172(4) of the Commercial Code, and the limited partner was liable to restore them. The Court also found that the payments out of the partnership assets was also in contravention of paragraph $30 \mathrm{GmbHG}$, because it had diminished the assets of the $\mathrm{GmbH}$ necessary for the preservation of its capital. It held that the limited partnership had a claim for the restoration of the payments under paragraph $31 \mathrm{GmbHG}$ which could be enforced by its liquidator.

The above principle was also applied in a case in which the limited partner was not a member of the $\mathrm{GmbH}$, BGHZ 110, 342. The question arises as to whether the provisions of paragraphs 30 and $31 \mathrm{GmbHG}$ could be applied in a general manner irrespective of an indirect reduction of the assets of the $\mathrm{GmbH}$, the unlimited partner. However, the Supreme Court has refused to make an extension of this principle, and has held that paragraphs 30 and 31 are applicable in the GmbH \& Co KG solely for the purpose of protecting the $\mathrm{GmbH}$ which is its unlimited partner.

The provisions of paragraphs 32a and 32b GmbH apply to capitalisation by loans in a GmbH. According to paragraph $32 \mathrm{a}(1)$, if a shareholder has made a loan to his company at a time when a careful businessman would have provided it with capital, he can only claim the return of the loan in insolvency proceedings as a deferred creditor. Paragraph $32 \mathrm{a}(2)$ contains a similar principle applicable to third parties who grant a loan to a company in the circumstances mentioned in paragraph $32 \mathrm{a}(1)$, and such loan is guaranteed by a shareholder or shareholders in insolvency proceedings, third parties who have granted such loans must enforce the security granted by the shareholder before claiming the balance in the insolvency proceedings. Furthermore, paragraph $32 \mathrm{a}(3)$ provides that the above provisions of paragraphs 32(a)(1) and (2) apply to other transactions by a shareholder or a third party which economically correspond to the grant of loans in accordance with such provisions.

According to paragraph $32 \mathrm{~b}$ GmbHG if a company has repaid a loan governed by paragraphs $32 \mathrm{a}$ (2) and (3) in the last year before the petition for the opening of insolvency proceedings, or after such petition, the shareholder who 
gave security for such a loan must repay the amount so repaid to the company.

Capitalisation by means of loans to a $\mathrm{GmbH} \& \mathrm{Co} \mathrm{KG}$ is dealt with by paragraph 172a of the Commercial Code. Paragraph $172 \mathrm{a}(1)$ provides that in a limited partnership in which no natural person is an unlimited partner, paragraphs 32a and 32b GmbHG apply by way of analogy to loans granted to the limited partnership by members of the private company and the limited partners. It was already recognised by the Supreme Court in a decision in 1977 BGHZ 67,171 that rules similar to those contained in paragraphs 32a and 32b GmbHG were applicable to loans to a $\mathrm{GmbH} \& \mathrm{Co} \mathrm{KG}$.

\section{LIABILITIES}

As already indicated, the corporate member of a $\mathrm{GmbH}$ \& Co KG has unlimited liability (paras 128 and 161, Commercial Code, and see also K Schmidt, op cit, p1668). Should a GmbH \& Co KG commence activities before it is entered in the Commercial Register of the place where it is situated the prospective limited partners may incur unlimited liability in accordance with paragraph 176 of the Commercial Code. However if the indication GmbH \& Co KG has been used when the relevant transaction has been entered into, such unlimited liability will not be incurred. If no such indication of the nature of the firm is given in transactions entered into after its registration the limited partners may incur unlimited liability. They may otherwise do so if they specifically agree at the request of a creditor that the $\mathrm{GmbH}$ shall be free from personal responsibility for the firm's debts.

\section{DISSOLUTION AND LIQUIDATION}

As far as the $\mathrm{GmbH} \& \mathrm{Co} \mathrm{KG}$, is concerned both the $\mathrm{GmbH}$ and the limited partnership are subject to rather different grounds for dissolution, and have their own different liquidation procedures. There are six grounds for the dissolution of a $\mathrm{GmbH}$, which are set out in paragraph $60 \mathrm{GmbHG}$; and seven for that of a limited partnership, which are set out in paragraph 131 of the Commercial Code.

An attempt should be made in the partnership agreement to harmonise the relevant grounds for liquidation. It has been much disputed whether the dissolution off the $\mathrm{GmbH}$ entails the dissolution of the limited partnership. According to paragraph 131 no 4 of the Commercial Code, the death of the personally liable partner entails the dissolution of the limited partnership. However, the Court of Appeal of Hamburg refused to take this view in case heard in 1987. The relevant GmbH had failed to raise its nominal capital from 20,000DM to 50,000DM and was thus dissolved.

However, the court refused to treat that as a ground for the dissolution of the partnership (NJW 1987, 1896). The problem with the judgment may have been that the court applied paragraph 131 no 4 of the Commercial Code by way of analogy to the situation, and treated the dissolution of the $\mathrm{GmbH}$ as not being equivalent to its "death" because it would survive until the closure of the liquidation. Professor Karsten Schmidt op cit, p 1663 argues that such an analogy was mistaken, and that the court could alternatively have decided that the $\mathrm{GmbH}$ could be continued by an appropriate resolution, and an increase of capital, to which its members would have been required to subscribe by reason of their duty of good faith towards the company.

A limited partnership may be dissolved by means of resiliation of the partnership agreement by any of the partners. This is possible if the partnership has an unlimited duration. This procedure is known as ordentliche Kündigüng, and cannot take place except at the end of the financial year. Six months notice of the intention to resile from the agreement has to be given (paragraph 132 of the Commercial Code). Furthermore, any partner may request the court to dissolve the limited partnership if he can show that there are grave reasons for so doing (paragraph 133 of the Commercial Code). This procedure is known as the ausserordentliches Aufösungsrecht.

These would be deemed to exist where one of the partners has intentionally or by reason of gross negligence failed to respect one of the essential obligations of the partnership, or where the performance of these obligations has become impossible. When deciding whether to dissolve the partnership, the court looks at all the circumstances of the case, the length of time the partnership has existed, its economic importance and the relationship between the partners. It also determines whether the matter can be settled $b$ any method other than the dissolution of the partnership, for example by the exclusion of the petitioning partner.

The personal creditor of a partner in a GmbH \& Co KG (including the $\mathrm{GmbH}$ ) is given the right to dissolve the partnership by the rather complex provisions of paragraph 135 of the Commercial Code. This paragraph provides that if the personal creditor of a partner has during the last six months sought enforcement against the movable assets of that partner without success, and effects, the basis of a not merely preliminarily enforceable debt instrument, a seizure and transfer of what is due to the partner in the event of dissolution, he may give notice to terminate the partnership within six months prior to the end of the relevant financial year. Such a dissolution may be avoided if the other partners agree that the partnership shall continue: the partner who is in debt receives the value of his share in the partnership, and ceases to be a member thereof. The use of this procedure (Kündigung durch einer Glaübiger) in the case of a $\mathrm{GmbH} \& \mathrm{Co}$ KG does not result in the dissolution of the $\mathrm{GmbH}$.

The liquidation of the $\mathrm{GmbH}$ and of the limited partnership are carried on by the liquidator of the $\mathrm{GmbH}$, 
who will usually be its manager (see para 66(1) GmbHG). The liquidator represents the entity which has been dissolved in relation to third parties. It is the task of a liquidator to terminate existing transactions, recover debts and realise assets. A liquidator may conclude new transactions, if necessary (para 149, of the Commercial Code). If the partnership is insolvent, two different insolvency procedures are necessary, which will usually be conducted by the same person.

\section{CONCLUDING REMARKS}

The GmbH \& Co KG will celebrate its centenary in 2012: this will no doubt result in a considerable addition to the voluminous literature which already exists relating to this entity, and may even give rise to further dogmatic disputes of a sometimes rather polemical nature. The $\mathrm{GmbH} \& \mathrm{Co} \mathrm{KG}$ is used in Austria, and a similar entity has been employed in France since the 1980's. However, the complex regime governing this entity does not seem one which is likely to lead to legal transplants in many other countries. Its use seems to be permissible in the United Kingdom.
The GmbH \& Co KG has proved a useful entity for small businesses in the past. Where such businesses have taken the form of a German limited partnership, the death of the Komplementär has often led to the dissolution of the limited partnership in accordance with paragraph 131 no 4 of the Commercial Code. This rule could always be excluded in the partnership agreement, but sometimes the parties to such an agreement failed to do so. In a GmbH \& Co KG, the Komplementär or unlimited partner, continues in being until the conclusion of its liquidation, and is unaffected by the death of one of the limited partners. This helps to explain the continued use of this legal form by family businesses. As mentioned above, the popularity of this type of entity in Germany can be explained by other factors a well; for example the desire for a favourable tax regime, and the diminished burden of codetermination. It has been used by undertakings having several hundred members, as well as by family businesses. The GmbH \& Co KG is likely to continue to be popular in Germany, and to be used for many different purposes in that country.

Dr Frank Wooldridge 